\title{
Transformed Hairy Roots of the actinorhizal shrub Discaria trinervis: a valuable tool for studying actinorhizal symbiosis in the context of intercellular infection
}

\author{
Leandro Imanishi ${ }^{1}$, Alice Vayssières ${ }^{2}$, Claudine Franche ${ }^{2 *}$, Didier Bogusz ${ }^{2}$, Luis Wall', Sergio Svistoonoff ${ }^{2}$ \\ From IUFRO Tree Biotechnology Conference 2011: From Genomes to Integration and Delivery \\ Arraial d'Ajuda, Bahia, Brazil. 26 June - 2 July 2011
}

\section{Background}

Nitrogen is a major limiting factor of plant growth in many ecosystems. Root nodule symbiosis (RNS) is one of the most efficient adaptations allowing plants to cope with nitrogen deficiency by establishing a symbiotic association with diazotrophic bacteria able to produce ammonium from atmospheric nitrogen. Nevertheless RNS is restricted to two groups of plants: legumes and Parasponia (Celtidaceae), that interact with a group of gram-negative proteobacteria collectively called rhizobia, and actinorhizal plants, a group of 220 species, mostly shrubs and trees distributed in the orders Fagales, Cucurbitales and Rosales, that interact with gram-positive actinomycetes of the genus Frankia[1]. All these plants belong to the Rosid I clade, suggesting a common origin for the ability to establish RNS [2].

In recent decades a strong research effort focused on model legumes lead to the identification of key molecular actors involved in nodulation, including the bacterial signalling molecules, the Nod factors and several genes involved in the symbiotic signalling pathways [3]. Much less is known in non model legumes and actinorhizal plants, particularly in species that are not infected like model legumes through root hairs but show more ancestral infection mechanisms like crack entry or intercellular infection. Yet important cues regarding the

\footnotetext{
* Correspondence: claudine.franche@ird.fr

${ }^{2}$ Groupe Rhizogenèse, Unité Mixte de Recherche Diversité Adaptation et Développement des Plantes (DIADE), Institut de Recherche pour le Développement (IRD), 911 avenue Agropolis, BP 5045, 34394 Montpellier Cedex 5, France

Full list of author information is available at the end of the article
}

diversity and evolution of RNS are being found precisely in these more primitive non-model systems $[4,5]$.

Among infection mechanisms leading to root nodule symbiosis, the intercellular infection pathway is probably the most ancestral but also one of the least characterized [6,7]. Intercellular infection has been described in Discaria trinervis, an actinorhizal shrub belonging to the Rosales order [8]. To decipher the molecular mechanisms underlying intercellular infection with Frankia, we set up an efficient genetic transformation protocol for $D$. trinervis based on A. rhizogenes.

\section{Methods}

We analyzed the susceptibility of $D$. trinervis to two strains of A. rhizogenes: A4RS, and ARqua1; both strains contained a pHKN29 plasmid with a 35S::GFP fusion [9]. The classic in-vitro inoculation was compared to an ex-vitro method reported to be successful in several plant species [10]. The functionality of the symbiosis was tested on composite plants by performing nodulation tests and acetylene reduction assays. Using this technique, we introduced the promoter of MtEnod11, a nodulin gene from $M$. truncatula widely used as a marker for early infection-related symbiotic events in model legumes [11].

\section{Results}

Transgenic roots showing strong levels of GFP were obtained for all treatments. The ex-vitro method using Arqua1 was the best compromise to obtain a good cotransformation efficiency while minimizing the impact on root system architecture. Co-transformed roots were specifically and efficiently nodulated with Frankia and 
the resulting nodules were undistinguishable from nontransgenic nodules in terms of developmental timing, anatomy, nitrogen fixation and feedback control by nitrogen. The expression of reporter genes such as GUS and GFP could be easily detected within transgenic $D$. trinervis root systems. The promoter of MtEnod11 retained its symbiotic activation in transgenic $D$. trinervis nodules. Similar results were obtained in C. glauca [12].

\section{Conclusions}

These findings open new avenues to study the genetic mechanisms of intercellular root invasion and single cell infection, allowing detailed characterization of genes involved in $D$. trinervis nodulation and a better understanding of the most ancestral infection pathways leading to RNS. In addition, because $D$. trinervis belongs to the Rosales order, evolutionary comparisons can be made with plants belonging to the same clade but unable to nodulate (most Rosaceae), or with Parasponia sp., the only non-legume able to enter RNS with rhizobia. The transformed roots in $D$. trinervis with appropriate reporter genes would be a powerful tool to explore signaling mechanisms in symbioses with this ancestral infection mode [13].

\section{Author details}

${ }^{1}$ Programa Interacciones Biológicas, Departamento de Ciencia y Tecnología, Universidad Nacional de Quilmes R. Sáenz Peña 352, B1876BXD Bernal, Argentina. ${ }^{2}$ Groupe Rhizogenèse, Unité Mixte de Recherche Diversité Adaptation et Développement des Plantes (DIADE), Institut de Recherche pour le Développement (IRD), 911 avenue Agropolis, BP 5045, 34394 Montpellier Cedex 5, France.

Published: 13 September 2011

\section{References}

1. Vessey JK, Pawlowski K, Bergman B: Root-based N 2-fixing symbioses: legumes, actinorhizal plants, Parasponia sp. and cycads. Plant Soil 2005, 266:205-230.

2. Soltis DE, Soltis PS, Morgan DR, Swensen SM, Mullin BC, Dowd JM, Martin PG: Chloroplast gene sequence data suggest a single origin of the predisposition for symbiotic nitrogen fixation in angiosperms. Proc. Natl. Acad. Sci. U.S.A 1995, 92:2647-2651.

3. Kouchi H, Imaizumi-Anraku H, Hayashi M, Hakoyama T, Nakagawa T, Umehara $Y$, Suganuma N, Kawaguchi M: How many peas in a pod? Legume genes responsible for mutualistic symbioses underground. Plant Cell Physiol 2010, 51:1381-1397.

4. Giraud E, Moulin L, Vallenet D, Barbe V, Cytryn E, Avarre JC, Jaubert M, Simon D, Cartieaux F, Prin Y: Legumes symbioses: absence of Nod genes in photosynthetic bradyrhizobia. Science 2007, 316:1307-1312.

5. Op den Camp R, Streng A, De Mita S, Cao Q, Polone E, Liu W, Ammiraju JSS, Kudrna D, Wing R, Untergasser A, Bisseling T, Geurts R: LysMtype mycorrhizal receptor recruited for rhizobium symbiosis in nonlegume Parasponia. Science 2011, 331:909-912.

6. Sprent J: Evolving ideas of legume evolution and diversity: a taxonomic perspective on the occurrence of nodulation. New Phytol 2007, 174:11-25.

7. Wall : The Actinorhizal Symbiosis. J. Plant Growth Regul 2000, 19:167-182.

8. Valverde C, Wall LG: Time course of nodule development in the Discaria trinervis (Rhamnaceae)-Frankia symbiosis. New Phytol 1999, 141:345-354.
9. Kumagai $\mathrm{H}$, Kouchi $\mathrm{H}$ : Gene silencing by expression of hairpin RNA in Lotus japonicus roots and root nodules. Mol. Plant Microbe Interact 2003, 16:663-668.

10. Collier R, Fuchs B, Walter N, Kevin Lutke W, Taylor CG: Ex vitro composite plants: an inexpensive, rapid method for root biology. Plant J 2005, 43:449-457.

11. Journet EP, El-Gachtouli N, Vernoud V, de Billy F, Pichon M, Dedieu A, Arnould C, Morandi D, Barker DG, Gianinazzi-Pearson V: Medicago truncatula ENOD11: a novel RPRP-encoding early nodulin gene expressed during mycorrhization in arbuscule-containing cells. Mol. Plant-Microbe Interact 2001, 14:737-748.

12. Svistoonoff S, Sy M-O, Diagne N, Barker DG, Bogusz D, Franche C: Infectionspecific activation of the medicago truncatula Enod11 early nodulin gene Promoter During actinorhizal root nodulation. Mol. Plant-Microbe Interact 2010, 23:740-747.

13. Imanishi $L$, Vayssières $A$, Bogusz $D$, Franche $C$, Wall LG, Svistoonoff S: Transformed Hairy Roots of Discaria trinervis: A valuable tool for studying actinorhizal symbiosis in the context of intercellular infection. Mol Plant Microbe Interact 2011.

doi:10.1186/1753-6561-5-S7-P85

Cite this article as: Imanishi et al:: Transformed Hairy Roots of the actinorhizal shrub Discaria trinervis: a valuable tool for studying actinorhizal symbiosis in the context of intercellular infection. BMC Proceedings 2011 5(Suppl 7):P85.

\section{Submit your next manuscript to BioMed Central and take full advantage of:}

- Convenient online submission

- Thorough peer review

- No space constraints or color figure charges

- Immediate publication on acceptance

- Inclusion in PubMed, CAS, Scopus and Google Scholar

- Research which is freely available for redistribution

Submit your manuscript at www.biomedcentral.com/submit 